\title{
Mean retention time in digestive tract and digestion of fresh perennial ryegrass by lactating dairy cows: influence of grass maturity and comparison with a maize silage diet
}

\author{
M Mambrini **, JL Peyraud * \\ with the collaboration of $\mathrm{H}$ Hetault, A Stephant and M Texier \\ INRA, Station de Recherches sur La Vache Laitière, F35590 Saint-Gilles, France
}

(Received 2 October 1993; accepted 18 October 1993)

\begin{abstract}
Summary - The effects of grass maturity on the mean retention time of liquid and particles, digestibility and duodenal nutrient flows were measured by feeding second cuts of perennial ryegrass to 3 fistulated lactating dairy cows over 2 successive periods (late June and mid-July, 28 and $49 \mathrm{~d}$ regrowth, respectively). Fresh forage was given ad libitum with $12 \%$ (dry matter (DM) basis) concentrate. The increase in maturity lowered grass nitrogen content, organic matter (OM) digestibility and non-ammoniacal nitrogen flow into the duodenum, but did not affect $O M$ intake $(13.2 \mathrm{~kg} / \mathrm{d})$. Neither the fractional outflow rate of liquid in the rumen (FOR; $17.3 \% / \mathrm{h}$ ) nor the concentrate total mean retention time (TMRT; $32.9 \mathrm{~h}$ ) were affected. With maturity forage TMRT tended to increase (43.0$48.8 \mathrm{~h}$ ), certainly because of the longer comminution time of coarse particles. These results were compared with data obtained 2 months earlier with the same cows fed on a maize silage diet $(25 \%$ DM basis of the same concentrate) ad libitum $(17.4 \mathrm{~kg} \mathrm{OM} / \mathrm{d})$. Despite a lower total OM intake, FOR was much higher with the grass than with the maize silage diet $(12.1 \% / h)$ and this may explain the lower retention time in the rumen of the small particles when grass diets were given (19.0 vs $24.3 \mathrm{~h}$ for maize silage diet).
\end{abstract}

dairy cow / passage rate / digestion / fresh grass / maize silage

Résumé - Temps de séjour moyen dans le tube digestif et digestion du ray-grass anglais par des vaches laitières : influence de l'âge des repousses et comparaison avec de l'ensilage de maïs. L'effet de l'âge des repousses du ray-grass anglais sur le temps de séjour des liquides et des particules, la digestibilité et les flux de nutriments à l'entrée du duodénum ont été étudiés chez 3 vaches laitières au cours de 2 périodes successives (fin juin et début juillet, 28 et $49 j$ de repousse). Le régime distribué ad libitum a été complémenté avec $12 \%$ (sur la base de la MS) de concentré. Le vieillissement de l'herbe a entraîné une diminution de la teneur en azote non ammoniacal à l'entrée du duodénum, mais les quantités ingérées n'ont pas été affectées $(13,2 \mathrm{~kg} \mathrm{MO} / \mathrm{j})$. Le taux de renouvellement des liquides dans le rumen $(K I ; 17,3 \% / h)$ et le temps de séjour moyen total (TSMT) du

* Correspondence and reprints.

** Present address: INRA, Station d'Hydrobiologie, Saint Pée sur Nivelle, BP3 F64310 Ascain, France. 
concentré $(32,9$ h) n'ont pas été modifiés. Le TSMT du fourrage a eu tendance à augmenter $(43,0$ à $48,8 \mathrm{~h}$ ), sûrement en raison d'un temps de comminution des particules plus long. Ces résultats ont été comparés à des données obtenues 2 mois auparavant sur les mêmes animaux, alors alimentés ad libitum $(17,4 \mathrm{~kg} \mathrm{MO} / \mathrm{j})$ avec un régime à base d'ensilage de maïs contenant $25 \%$ du même concentré. Bien que les quantités ingérées aient été inférieures, le Kl a été bien plus élevé avec le régime herbe qu'avec le régime ensilage de maïs $(12,5 \% / \mathrm{h})$, ce qui peut expliquer un temps de rétention des petites particules dans le rumen beaucoup plus faible avec le régime herbe $(19,0$ contre 24,3 h pour l'ensilage de maïs).

vache laitière / vitesse de passage / digestion / ray-grass anglais / ensilage de maïs

\section{INTRODUCTION}

Food intake and the extent of digestion of forage are related to the retention time of feed residues in the digestive tract (Bull et al, 1979; Mertens and Ely, 1982). Factors influencing the rate of passage of undigested residues have been extensively studied in sheep, whilst more specific information in dairy cows has been obtained over the last $10 \mathrm{yr}$ (Hartnell and Satter, 1979; Snyder et al, 1984; Shaver et al, 1986, 1988; Mambrini et al, 1988; Peyraud et al, 1989). However, data regarding fresh forage are still lacking, although it is a major feedstuff given to dairy cows for half of the year in western Europe. Indeed, the digestive transit of fresh forage has only been examined in steers grazing low fertilized native rangeland (Krysl et al, 1987) or in tropical pastures (Pond et al, 1987). These studies concluded that there was an increase in the retention time of particles with advancing plant maturity. However, these data need confirmation for highly digestible fresh forage given to dairy cows. Compared generally to conserved forages, fresh grass has high water content, high digestibility and low level of lignified cell walls. These characteristics may lead to particular features in the rumen dynamics of liquid and particles. However, there appears to be no direct comparison between fresh and conserved diets in the literature.
The aims of this study were to measure the effect of plant maturity ( 28 and $49 \mathrm{~d}$ regrowth) of fresh perennial ryegrass on the rate of passage of liquid and forage and concentrate particles, and on the duodenal flows in 3 dairy cows and to compare them with those of a conserved diet based on maize silage and the same concentrate. A preliminary report of part of this work has previously been published (Mambrini and Peyraud, 1992).

\section{MATERIAL AND METHODS}

\section{Digestive characteristics of fresh grass diet}

\section{Management of sward, animals and feed}

A plot of perennial ryegrass (Lolium perenne, $\mathrm{L}$ cv Vigor) was fertilized with $60 \mathrm{~kg}$ nitrogen per ha after the first cut (20 May, 1988) and was harvested at 2 different stages of leafy regrowth: 23-34 d (young) and 44-55 d (more mature). Three holstein cows $(658 \pm 70 \mathrm{~kg})$ with a ruminal and T-piece duodenal cannula between 40 and 43 weeks of lactation ( $13 \pm 3 \mathrm{~kg} / \mathrm{d}$ of milk) were housed in metabolic crates and milked twice daily. They were fed ad libitum (10\% refusals) during 2 successive periods of 2 weeks on ryegrass and received a constant supply of $1.7 \mathrm{~kg}$ dry matter (DM) of concentrate per day. The diet finally (in \% of the total DM) consisted of $85 \%$ fresh grass, $12 \%$ concentrate and $3 \%$ mineral 
mix. The diet supplementation was performed in order to compare the transit of the same concentrate when associated with grass or with maize silage (see below). Additional mineral and vitamins were provided by means of $0.3 \mathrm{~kg}$ of a feed containing $30 \%$ minerals. The chemical composition of the feeds are shown in table I. The animals had free access to water and to a mineral block. The grass was harvested daily at $09.00 \mathrm{~h}$ and held at $4^{\circ} \mathrm{C}$ until required. The herbage was cut to $5 \mathrm{~cm}$ above ground level and picked up without being chopped by means of a forage wagon equipped with a motorscythe. The grass was given in 3 equal meals at 07.30 , 14.30 and $21.30 \mathrm{~h}$, and the concentrate was distributed in 2 meals (07.30 and $21.30 \mathrm{~h}$ ). Feeds refusals and water intake were recorded once daily at $07.30 \mathrm{~h}$ during each experimental period. Representative samples of the grass offered and refused were taken daily to determine DM content. The samples for each week were pooled for the determination of the organic matter $(O M)$, nitrogen $(N)$ and neutral detergent fiber (NDF) contents. Samples of concentrate and mineral feed were taken once a week for $\mathrm{DM}, \mathrm{OM}, \mathrm{N}$ and NDF analysis as appropriate.

\section{Organization of experimental period}

Since the nutritional characteristics of fresh forage change quickly, an experimental schedule was developed to measure the rate of passage and duodenal nutrient flows simultaneously over an 11-day experimental period. Polyethylene glycol 4000 (PEG) was pulse-dosed into the rumen for the determination of liquid dynamics.
Ytterbium chloride ( $\mathrm{YbCl})$ and PEG were then perfused simultaneously into the rumen for duodenal flow determination, and forage and concentrate labelled respectively with europium (Eu) and dysprcsium (Dy) were given as a test meal to follow tneir passage through the digestive tract.

Fractional sutflow rate of liquid in the rumen (FOR) was $\pi$ easured on days 1 and 2 . A dose of PEG (25, / $/ \mathrm{kg}$ DM ingested diluted in 1 I water) was intr sduced into the rumen on day 1 at $08.00 \mathrm{~h}$. R umen fluid was sampled at 10.00 , 10.30 and $11.00 \mathrm{~h}$ on days 1 and 2 , strained through 6 ayers of cheesecloth and stored at $4^{\circ} \mathrm{C}$ until z ralysis. Duodenal nutrient flows were obtained from continuous intra-ruminal perfusions of PEG $(250 \mathrm{~g} / \mathrm{d} / \mathrm{cow})$ and $\mathrm{YbCl}(2 \mathrm{~g} \mathrm{Yb} / \mathrm{d} /$ cow). Perfusions performed using 2 multichannel peristaltic pumps were begun on day 2 at $14.00 \mathrm{~h}$, after a priming dose, and maintained until day 11. Eighteen spot samples of duodenal contents $(350 \mathrm{ml})$ were taken between days 8 and 10 in order to distribute them evenly over a mean day (every $80 \mathrm{~min}$ ). A $20-\mathrm{ml}$ aliquot was stored at $4^{\circ} \mathrm{C}$ for PEG analysis and the remaining samples were pooled and frozen at $-20^{\circ} \mathrm{C}$. $\mathrm{DM}, \mathrm{OM}, \mathrm{N}$ and ammonia were determined on fresh samples; $\mathrm{Yb}$, neutral detergent fiber and acid detergent lignin were analyzed after freezedrying. Rumen fluid was sampled at the same time as duodenal content; $\mathrm{pH}$ was measured immediately, the sample was strained and the filtrates were pooled, frozen, and analyzed for volatile fatty acids (VFA) and ammonia.

For the measurement of particle passage, feedstuffs were labelled with rare earth metals

Table I. Chemical composition of fresh perennial ryegrass harvested at 2 stages of regrowth 23-24 d (YG) and 44-55 d (MG) and of concentrate a.

YG $\quad M G \quad$ Concentrate $^{\mathrm{b}}$ Mineral mix

$\begin{array}{lrrrr}\text { DM content ( } \mathrm{g} / 100 \text { fresh weight) } & 18.1 & 19.8 & 90.2 & 91.4 \\ \text { Organic matter }(\mathrm{g} / 100 \mathrm{~g} \mathrm{DM}) & 89.1 & 91.6 & 91.7 & 65.7 \\ \text { Crude protein }(\mathrm{g} / 100 \mathrm{~g} \mathrm{DM}) & 17.4 & 9.5 & 13.1 & 6.0 \\ \text { Neutral detergent fiber }(\mathrm{g} / 100 \mathrm{~g} \mathrm{DM}) & 51.6 & 52.3 & 28.1 & 13.2\end{array}$

a The diets contained $(\mathrm{g} / 100 \mathrm{~g} \mathrm{DM}): 85$ fresh grass, 12 concentrate and 3 mineral mix; ${ }^{\mathrm{b}}$ concentrate composition $(\mathrm{g} / 100 \mathrm{~g} \mathrm{DM})$ : 25 barley, 25 wheat bran, 30 dry beet pulp, 10 dehydrated lucerne, 5 sugar beet molasses, 1 fat, 2 $\mathrm{Na}_{2} \mathrm{CO}_{3}, 1 \mathrm{CaHPO}_{4}, 1 \mathrm{NaCl}$. 
using a competitive binding technique adapted from Ellis and Beever (1984) and Poncet (personal communication). The cell-wall constituents of feedstuffs were extracted by means of a commercial detergent (Ergamatic AC, Société Chimiotechnique, Lyon, France) at $80^{\circ} \mathrm{C}$ for $1 \mathrm{~h}$. The residues were soaked in a water bath containing the rare earth element $(20 \mathrm{~g} / \mathrm{kg} D M)$ and citric acid as a competitive ligand, the $\mathrm{pH}$ was brought to $2.2-2.5$ using $2 \mathrm{~N} \mathrm{HCl}$. After an immersion of $24 \mathrm{~h}$, the labelled feedstuffs were carefully rinsed. The grass was dried by centrifugation and the concentrate was dried at $60^{\circ} \mathrm{C}$ for $48 \mathrm{~h}$. Labelled fresh grass contained $11.8 \mathrm{~g}$ Eu/kg DM and concentrate, $9.0 \mathrm{~g}$ Dy/kg DM. Labelled feedstuffs $(600$ and $500 \mathrm{~g} \mathrm{DM}$ for grass and concentrate, respectively) were offered on day 3,30 min before the morning meal. After $45 \mathrm{~min}$, any uneaten grass was chopped (5 cm long), soaked in artificial saliva at $40^{\circ} \mathrm{C}$ and introduced into the rumen via the cannula. The total faecal output was collected 22 times during the $178 \mathrm{~h}$ post-dosing with increasing intervals (from 2-12 h). Faecal samples $(500 \mathrm{~g}$ ) were dried, ground through a $0.8 \mathrm{~mm}$ screen and analyzed for Eu and Dy. During the last $5 \mathrm{~d}$ (days 6 to 11), the faecal samples collected were also used to determine the digestibility of the diet and the recovery rate of markers used for duodenal flow determination.

\section{Calculations}

FOR was estimated as the slope of the regression of the natural logarithm of PEG concentration vs time post-dosing. Ruminal liquid volume was obtained after dividing the quantity of $P E G$ dosed by the calculated concentration at zero time. Rumen liquid outflow was calculated as the product of FOR and the volume. Duodenal digesta flow was calculated by dividing daily quantities of $\mathrm{Yb}$ and $\mathrm{PEG}$ recovered in faeces by their respective equilibrium concentrations in duodenal digesta. The mean value of the 2 estimates was retained. Total mean retention time in the digestive tract (TMRT) of forage or concentrate particles was calculated using the equation:

$$
\text { TMRT }=\frac{\sum m_{i} t_{i}}{\sum m_{i}}
$$

where $t_{i}$ is the time elapsed between dosing the mid-point of each interval $i$ during which faeces were collected, and $m_{i}$ the quantity of marker excreted in the th interval. Faecal marker excretion curves were analyzed in order to estimate retention time in the rumen according to Uden (1984). The calculations were as follows. The natural logarithm of marker concentration was plotted $v s$ time. The curve was divided into a linear descending part, a curve linear ascending part and a delay (TT). TT was determined by the time elapsed between dosing and the mid-point of interval where marker appeared for the first time. T1 was calculated by the reverse of the slope of the descending part of the curve. T2, corresponding to the ascending part, was obtained by subtracting $\mathrm{T} 1+\Pi$ from TMRT. The physiological implications of these 3 parameters were determined by Mambrini (1990). Briefly, 4 fistulated cows were fed a hay-based diet and received a test meal consisting of coarse hay labelled with thullium and ground hay (mean particle size $0.64 \mathrm{~mm}$ ) labelled with $\mathrm{Yb}$. Duodenal digesta and faeces were collected and TMRT, $T 1, T 2$ and TT were calculated as previously described. The time T1 was associated with the retention time of small particles in the rumen (ie having a high probability of exit) because it did not differ according to the hay particle size and to the sampling site. The time T2 was associated with: i) the time of the comminution of coarse particles, because the difference between long and ground hay TMRT was totally recovered in T2, regardless of the sampling site; and ii) the time spent in a small distal mixing compartment (ie caecum), as the sum $T 1+T 2$ in faeces was highly correlated with but $3 \mathrm{~h}$ longer than TMRT calculated from duodenal digesta. The time TT calculated on faecal kinetics and not observed on duodenal kinetics, was assumed to be the time necessary for the labelled feedstuffs to mix with the rumen content and to transit through the tubular segments.

\section{Chemical analysis}

Dry matter was determined by drying at $80^{\circ} \mathrm{C}$ over a period of $48 \mathrm{~h}$ and $\mathrm{OM}$ content by ashing for $5 \mathrm{~h}$ at $550^{\circ} \mathrm{C}$. Nitrogen was obtained by the Kjeldahl method. Neutral detergent fiber was analyzed according to Van Soest (1963) on Fibertec (Tecator) as described by Giger and Pochet (1987). For ammonia determination, the method of Berthelot was adapted to an autoanalyzer. Volatile fatty acid composition was analyzed using gas-liquid chromatography on a 
column $1.5 \mathrm{~m}$ long $\times 2 \mathrm{~mm}$ id packed with nitrogen as the vector gas, according to Jouany (1982). Concentrations of PEG were analyzed using Hyden's turbidimetric method (1955) modified by Malawer and Powell (1967). The rare earth metals were determined by atomic absorption spectrophotometry, after the samples had been ashed $\left(550^{\circ} \mathrm{C}, 6 \mathrm{~h}\right)$ and digested in a solution containing $2 \%$ nitric acid and $2 \mathrm{~g} / \mathrm{l}$ potassium chloride. Previous studies had indicated no interaction between the determination of the 3 rare earth metals.

\section{Statistical analysis}

The results were analyzed with an analysis of variance with grass maturity (1 degree of freedom) and individual effects ( 2 degrees of freedom) as main factors, using the general linear models procedure (GLM; SAS, 1987). To compare the retention times of forage and concentrate particles, the data were pooled and analyzed by means of an analysis of variance taking into account the effects of the mature of the feedstuff (1 degree of freedom), the nature of the diet and the individual effects. Significance was determined at $P<0.10$ unless otherwise indicated.

\section{Comparison with maize silage diet}

The maize silage diet was given to the same animals 9 weeks before the fresh grass diet. Cows $(673 \pm 76 \mathrm{~kg})$ were then in mid-lactation (32-35 weeks post-partum) and produced $32 \pm$ $2 \mathrm{~kg}$ of milk. The diet, given in 2 equal meals $(08.00$ and $17.00 \mathrm{~h})$, consisted of (\% of the total DM) $65 \%$ maize silage, $25 \%$ of the same concentrate as used in experiment $1,8 \%$ soybean meal, $0.5 \%$ urea and $1.5 \%$ mineral vitamin mix. The composition of the maize silage was $37.2 \%$ DM and, on a DM basis, $95.3 \% \mathrm{OM}$ and $8.0 \%$ crude protein. The diet was given ad libitum $(10 \%$ refusals) and feed refusals were recorded once daily. Cows had free access to water and to a mineral block. Digestion and rate of passage were measured as previously described. However, only 3 markers were used and the experimental period lasted for $23 \mathrm{~d}$. The duodenal nutrient flows ( $\mathrm{Yb}$ and $\mathrm{PEG}$ ) were measured after the determinations of liquid dynamics in the rumen and mean retention times of maize silage and concentrate labelled with $\mathrm{Yb}$ and Eu respectively. Maize silage was labelled after the grains had been discarded.

The statistical analysis was performed with an analysis of variance. Main effects were partitioned into the nature of the diet (young, more mature grass and maize silage, 2 degrees of freedom) and individual effect (2 degrees of freedom). The GLM procedure was used (SAS, 1987). When the effect was significant the means were compared by the Newman and Keuls multiple range test at the 0.05 significance level.

\section{RESULTS}

\section{Characteristics of fresh grass diets}

With advancing maturity, crude protein content $\left(\mathrm{N}^{*} 6.25\right)$ of grass decreased markedly but the other chemical parameters were not changed (table I). The increase in maturity did not affect $O M$ intake but $O M$ digestibility was reduced $(P<0.03)$ and the proportion of digestible OM intake (DOMI) apparently digested in the rumen was also slightly reduced $(P<0.07$; table II), whilst this proportion remained unchanged for NDF (0.94). NDF digestibility was reduced as a consequence of delayed harvesting $(0.794$ and 0.695 for young and more mature grass, respectively; $P<$ $0.01)$. With the older regrowth, $N$ intake was strongly decreased $(P<0.002$; table II) due to the low $N$ content of grass. Total apparent digestibility of $\mathrm{N}$ was also reduced although the quantity of $\mathrm{N}$ excreted in faeces decreased $(P<0.03)$ from 8.3 for the young grass to $6.9 \mathrm{~g} / \mathrm{kg}$ OM intake for the more mature grass. The duodenal flow of non-ammoniacal N (NAN) was always higher than the total $N$ intake. This difference was even more striking for the more mature grass. Nonetheless, the greater maturity reduced total NAN flow by $17 \%$ $(P<0.05)$ and tended to lower NAN supply 
Table II. Digestion of organic matter and nitrogen in 3 dairy cows fed a diet based either on fresh perennial ryegrass harvested at 2 stages of regrowth (trial 1) 23-34 $d$ (YG) and 44-55 $d$ (MG) or on maize silage (MS; trial 2).

\begin{tabular}{|c|c|c|c|c|c|}
\hline & YG & $M G$ & $S E M^{\mathrm{a}}$ & MS & $S E M^{\mathrm{b}}$ \\
\hline \multicolumn{6}{|l|}{ Organic matter } \\
\hline Intake $(\mathrm{kg} / \mathrm{d} /)$ & 13.1 & 13.2 & 0.44 & 17.4 & 0.12 \\
\hline Entering the duodeum $(\mathrm{kg} / \mathrm{d})$ & 6.7 & 7.0 & 0.11 & 10.1 & 0.74 \\
\hline Apparent digestibility & 0.803 & 0.750 & 0.007 & 0.725 & 0.012 \\
\hline Ruminal digestion $(\mathrm{kg} / \mathrm{kg}$ DOMl $\mathrm{c})$ & 0.612 & 0.626 & 0.033 & 0.581 & 0.077 \\
\hline \multicolumn{6}{|l|}{ Nitrogen $(\mathrm{N})$} \\
\hline Intake $(g / d)$ & 374 & 240 & 5 & 426 & 10 \\
\hline Entering the duodenum as $\operatorname{NAN}^{d}(\mathrm{~g} / \mathrm{d})$ & 412 & 340 & 12 & 416 & 19 \\
\hline (g/kg DOMI a) & 39.3 & 34.1 & 1.6 & 32.7 & 2.2 \\
\hline ( $g / g N$ intake) & 115 & 135 & 5.7 & 89 & 7.2 \\
\hline Apparent digestibility & 0.710 & 0.623 & 0.001 & 0.676 & 0.008 \\
\hline
\end{tabular}

a Standard error of mean of the analysis of variance testing the effect of advancing maturity of the fresh grass diet (trial 1); ${ }^{\mathrm{b}}$ standard error of mean of the analysis of variance testing the difference between the 3 diets (trial 2); c DOMI, digestible organic matter intake; d NAN, non-ammoniacal nitrogen.

as a fraction of DOMI although the difference failed to be significant (table II). Ruminal $\mathrm{pH}$ was slightly increased with the more mature grass $(P<0.10$; table III). The total amount of VFA was not significantly influenced by the diet, greater maturity caused a decrease in the proportion of isoacids, propionate $(P<0.05$; table III). The rumen ammonia level was also reduced $(P<0.01)$.

Greater maturity of the grass did not alter FOR, caused a slight but nonsignificant increase of the rumen volume and increased the rumen liquid outflow $(P<0.05$; table IV). When eating the more mature grass, the cows drunk less $(P<$ 0.002 ), and due to the higher DM content of this grass, the total water intake was lower $(P<0.002)$. Concentrate TMRT was unaffected by advancing maturity. Grass
Table III. Rumen parameters of dairy cows fed a diet based on fresh ryegrass havested at 2 stages of regrowth, 23-34 $d(Y G)$ and $44-55 d$ (MG).

\section{YG MG SEM}

\begin{tabular}{lrrr}
$\mathrm{pH}$ & 6.41 & 6.55 & 0.06 \\
$\mathrm{NH}_{3}$ (mg/l) & 64.9 & 25.1 & 3.12 \\
$\mathrm{VFA}^{\mathrm{b}}(\mathrm{mM} / \mathrm{l})$ & 97.2 & 91.5 & 3.70 \\
$\mathrm{C} 2$ (molar \%) & 65.0 & 66.3 & 0.58 \\
$\mathrm{C} 3$ (molar \%) & 20.9 & 19.1 & 0.52 \\
$\mathrm{C} 4$ (molar \%) & 11.3 & 12.5 & 0.17 \\
Isoacids $^{\mathrm{c}}$ (molar \%) & 1.7 & 1.2 & 0.17 \\
Other minor acid (molar \%) & 1.1 & 0.9 & 0.12 \\
\hline
\end{tabular}

a Standard error of mean of the analysis of variance testing the effect of advancing maturity of the fresh grass diet; ${ }^{b}$ volatile fatty acids; ${ }^{c}$ isobutyric and isovaleric acids. 
Table IV. Water intake and rumen liquid dynamics in dairy cows fed a diet based either on fresh perennial ryegrass harvested at 2 stages of regrowth (trial 1) 23-34 $d$ (YG) and 44-55 d (MG) or on maize silage (MS; trial 2).

\begin{tabular}{|c|c|c|c|c|c|}
\hline & $Y G$ & $M G$ & $S E M^{a}$ & $M S$ & $S E M^{\circ}$ \\
\hline Water drunk (I/d) & 32 & 15 & 1.1 & 59 & 0.5 \\
\hline Total water intake $c(1 / h)$ & 97 & 67 & 4.3 & 83 & 2.5 \\
\hline Liquid fractional outflow rate $(\% / h)$ & 16.9 & 17.6 & 0.3 & 12.1 & 0.2 \\
\hline Rumen liquid volume (I) & 61 & 70 & 2.7 & 99 & 3.4 \\
\hline Rumen liquid outflow $(\mathrm{l} / \mathrm{d})$ & 247 & 296 & 9 & 288 & 12 \\
\hline
\end{tabular}

a Standard error of mean of the analysis of variance testing the effect of advancing maturity of the fresh grass diet (trial 1); ${ }^{b}$ standard error of mean of the analysis of variance testing the difference between the 3 diets (trial 2);

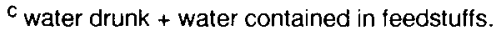

Table V. Total and partial mean retention times (h) of forage and concentrate in dairy cows fed a diet based either on fresh perennial ryegrass harvested at 2 stages of regrowth (trial 1) 23-34 d (YG) and 44-55 d (MG) or on maize silage (MS; trial 2).

\begin{tabular}{|c|c|c|c|c|c|}
\hline & $Y G$ & $M G$ & SEM a & MS & $S E M^{\mathrm{b}}$ \\
\hline \multicolumn{6}{|l|}{ Forage particles } \\
\hline Total mean retention time & 43.0 & 48.8 & 2.1 & 49.7 & 1.5 \\
\hline $\mathrm{T} 1 \mathrm{c}$ & 19.0 & 19.0 & 1.5 & 24.3 & 1.8 \\
\hline $\mathrm{T} 2 \mathrm{c}$ & 11.6 & 19.8 & 1.6 & 12.6 & 2.5 \\
\hline Tा $\mathrm{c}$ & 12.4 & 10.0 & 0.7 & 12.8 & 0.8 \\
\hline \multicolumn{6}{|l|}{ Concentrate particles } \\
\hline Total mean retention time & 32.6 & 33.1 & 0.3 & 36.5 & 0.3 \\
\hline $\mathrm{T} 1^{\mathrm{c}}$ & 17.6 & 16.1 & 0.7 & 20.2 & 0.9 \\
\hline $\mathrm{T} 2^{\mathrm{c}}$ & 6.5 & 9.1 & 0.7 & 3.5 & 0.8 \\
\hline Tा $\mathrm{c}$ & 8.5 & 7.9 & 0.4 & 12.8 & 0.8 \\
\hline
\end{tabular}

a Standard error of mean of the analysis of variance testing the effect of advancing maturity of the fresh grass diet (trial 1); ${ }^{\mathrm{b}}$ standard error of mean of the analysis of variance testing the difference between the 3 diets (trial 2 ); ${ }^{\mathrm{c}}$ from the analysis of the faecal marker excretion curves according to Uden (1984).

TMRT tended to increase $(5.8 \mathrm{~h}$ on the mean; table $V$ ) but there were large between-cow variations. Forage TMRT increased up to $8.9 \mathrm{~h}$ for the 2 cows with the shortest TMRT (mean of $38 \mathrm{~h}$ for the young grass) but was not affected for the cow with the longest TMRT (52.6 $\mathrm{h}$ for the young grass). However, T2 was always longer with more mature grass, either for forage $(P<0.07)$ or for concentrate $(P<$ $0.10)$ particles whilst T1 and TT were not affected (table V). Forage TMRT (45.9 h) 
was strikingly longer than concentrate TMRT (32.9 h; $P<0.01)$, as a consequence of the longer T2 $(P<0.05)$ of forage particles (15.7 vs $7.8 \mathrm{~h}$ for concentrate), T1 and TT being similar for all feedstuffs.

\section{Comparison with maize silage diet}

Compared with fresh grass diets (table II), $\mathrm{OM}$ and $\mathrm{N}$ intakes were much higher $(P<$ 0.05 ) with the maize silage diet, OM digestibility was lower $(P<0.05)$ but the proportion of DOMI apparently digested in the rumen was not affected ( $P>0.10$; table II). Total apparent $\mathrm{N}$ digestibility ranked the diets in the following order: mature grass < maize silage $<$ young grass $(P<0.05)$. The NAN flow relative to DOMI tended to be higher with fresh grass diets, unless the difference was not significant $(P>0.10)$. Cows drunk more water with the maize silage diet $(P<0.05)$ but considering the dry matter of feedstuffs, total water intake was not different between young grass and maize silage $(P>0.10$; table IV). Compared with fresh grass diets, FOR was much lower $(P<0.05)$ and rumen volume higher $(P<0.05)$ with the maize silage diet (table IV). There was no direct effect $(P>$ 0.10 ) of the nature of the diet on rumen liquid outflow (table IV). Maize silage TMRT tended to be greater than young grass TMRT but was not different from that measured with the more mature grass $(P<0.10$; table $V)$. This was explained by a relatively shorter T1 for grass diets $(P<$ 0.10 ), balanced only for the more mature grass diet by a relatively longer T2. The total mean retention time of the concentrate associated with maize silage was lower than forage TMRT $(P<0.05)$, as already observed for the grass diets. Concentrate TMRT was longer $(P<0.05)$ when associated with maize silage than with fresh grass. This difference was ex- plained by longer T1 $(P<0.05)$. The opposite was true for T2, which was lower $(P<$ 0.05 ) with the maize silage diet (table $V$ ). There were large individual variations of TMRT (variation coefficient of 13 and $8 \%$ for forage and concentrate, respectively). Individual differences outlined for grass diets were also found with the maize silage. The cows showing the highest TMRT when fed on grass, also had the highest TMRT when fed on maize silage (54.9 vs 48.3 and 45.8 for the other 2 cows). These differences were explained by higher $\mathrm{T} 1$, T2 and TT $(P<0.05)$. Between-cow differences were also found in concentrate TMRT.

\section{DISCUSSION}

Knowing the high individual variability of digestive transit (Hartnell and Satter, 1979; Ørskov et al, 1989), the experimental schedule was chosen in order to feed the 3 diets consecutively to the same cows. However, due to the time elapsed between the periods of measurement, it must be borne in mind that treatment effects may be confounded by time and stage of lactation. This confounding is unimportant in the first experiment (2 successive 14-d periods) but might not be completely excluded for the comparison between maize silage and grass diets (9-week interval). Nonetheless, passage of liquid and particles in the digestive tract of dairy cows is strongly affected only during the dry period and the first month of lactation (Doreau and Rémond, 1982; Doreau et al, 1990; Mambrini, 1990). Otherwise a reversal design experiment would have required several long periods for adaptation to the diet.

Without a reference value, validation of duodenal flow estimates is difficult. One approach could be to compare lignin flow in duodenum and lignin intake or output in faeces. Faecal acid detergent lignin was 
determined on grass diets. The estimated duodenal lignin flow was higher $(+15 \%)$ than, but highly correlated $(r=0.90)$ with, faecal acid detergent lignin output. This suggests that the method used in the pesent experiment is reliable to compare diets although the actual flows might be slightly overestimated. Actual values of NAN flows were $8 \%$ higher than the estimates obtained by a linear regression established by Peyraud (1994) on 40 data reported in the literature on fresh grasses given to cattle and dairy cows (NAN flow = $0.18 \mathrm{~N}$ ingested + 28.6 DOMI, giving 368 and $326 \mathrm{~g} / \mathrm{d}$ for the young and the more mature grass, respectively).

Different models have been proposed to study particle dynamics within the gastrointestinal tract. Besides the proposed method, models described by Grovum and Williams (1973, GW model), Ellis et al (1979) with a time-dependent passage rate following a gamma 3 distribution (E3 model) and Dhanoa et al (1985; DH model) were also examined but they were not retained. Firstly, in some cases, the nonlinear iterative procedure did not converge (NLIN procedure, Marquardt algorithm, SAS, 1987). On 2 occasions faecal marker excretion patterns could not fit the $\mathrm{DH}$ model. For the same reason, the GW model had to be solved by the linear method initially proposed by Grovum and Williams (1973). Secondly, TMRT (algebraic method) may be considered as a reference value because it is based on the quantitative recovery of markers and is calculated without any assumption about marker excretion. In contrast, all models assume that faecal excretion is a continuous process. Fitting models provided mean estimates of total MRT that did not differ from TMRT but increased the variability of the estimates as shown by the residual standard deviation of the relationships between those estimates and TMRT (table VI and Mambrini et al, 1988). This may reflect curve fitting inadequacy and surely limits the use of such models. Lastly, the physiological allocation of the different compartments of the models remains unclear. Times spent in the first compartment of the $\mathrm{DH}$ model, assumed to be the rumen retention times, provided mean values that were close to, and highly correlated $(r=0.95)$ with, T1. However this model has dramatically overestimated the time of first appearance of the marker in faeces (table VI). Similarly, physiological components of the GW model are obscure for forages because the time of first appearance of marker in the faeces was also overestimated. In contrast, the E3 model provided a delay and a time spent in the second compartment that were close to TT and T2, suggesting that this model fits the first steps of the faecal kinetics adequately. However, the time spent in the first compartment was lower than T1 (table VI). So, we inferred that no confidence could be placed in the estimations of rumen retention time due to their variations with the different models. We preferred to use the method for which we had determined the physiological implications of the parameters.

\section{Characterization of grass diets}

The decrease of OM digestibility with plant maturity is well known (INRA, 1989). Nonetheless, the values remained high for the more mature grass. This result is explained by the decrease of NDF digestibility. Actually, the level of indigestible cellwall material (total NDF content minus digestible NDF content) increased from 112 for the young to $162 \mathrm{~g} / \mathrm{kg}$ OM for the more mature grass. Because this study suggests that the decrease in digestibility is not due to a lower rumen mean retention time, it may be related either to characteristics of plant cell walls or to lower cellulolytic activity in the rumen. Nylon bag incubations 
Table VI. Comparison between modelling methods for estimating total and partial mean retention times $(h)$ in the gastrointestinal tract and the proposed method $(n=18)$.

Proposed method $\quad G W^{a} \quad E 3^{b} \quad D H^{c}$

Total mean retention time

$\begin{array}{lcrrr}\text { Forages } & 47.1 & 45.6 & 47.6 & 48.4 \\ \text { Concentrates } & 33.9 & 35.0 & 32.7 & 38.2 \\ \text { rsd d } & - & 2.9 & 1.8 & 2.5\end{array}$

Mean retention time in the first compartment

$\begin{array}{lcrrr}\text { Forages } & 20.8 & 20.3 & 17.1^{*} & 19.7 \\ \text { Concentrates } & 17.8 & 18.9 & 14.6^{\star} & 18.3 \\ \text { rsd d } & - & 2.3 & 3.0 & 2.2\end{array}$

Mean retention time in the second compartment

$\begin{array}{lcccc}\text { Forages } & 15.3 & 10.4^{\star} & 17.7 & 6.3^{\star} \\ \text { Concentrates } & 6.4 & 5.6 & 6.7 & 3.5^{\star} \\ \text { rsd }{ }^{d} & - & 2.1 & 2.9 & 0.8\end{array}$

Time of first appearance of marker

$\begin{array}{lcccc}\text { Forages } & 10.6 & 14.8^{\star} & 12.2^{\star} & 22.3 \\ \text { Concentrates } & 9.4 & 10.1 & 10.9 & 15.0^{*} \\ \text { rsd }^{d} & - & 2.2 & 1.6 & 4.6\end{array}$

a Model proposed by Grovum and Williams (1973); ${ }^{b}$ model proposed by Ellis et al (1979) with a time-dependent passage following a gamma 3 distribution; ${ }^{c}$ model proposed by Dhanoa et al (1985); d residual standard error of the regression between the parameter estimated after fitting the model and the parameter of the proposed method (Uden, 1984); " significantly different from the parameter calculated with the proposed method (tested with a paired t-test, $P<0.05$ )

were not carried out in the present study but Legoffe (1991) showed that the rate of degradation of DM decreases as the plant matures. Similar results were obtained from a first and a second cut of fresh ryegrass in our laboratory (JL. Peyraud, unpublished results). The lower fiber digestibility may be also related to ruminal characteristics and, in particular, the low levels of ammonia could have limited cellulolytic activity (Hoover, 1986). Indeed, Kennedy et al (1992) found that digestion rate of forage cell wall incubated in situ was depressed below the rumen ammonia level of 25 to $50 \mathrm{mg} \mathrm{N} /$.

The advanced maturity had no major effect on the site of digestion of DOMI. Ap- parent rumen digestion accounted for 0.62 of DOMI, which is slightly less than data recorded for fresh ryegrass diets fed to growing cattle (Beever et al, 1985). This may be either related to the slight overestimate of duodenal flow previously mentioned or to species differences. The decrease of NAN flow with grass maturity is in accordance with previously reported results (Beever et al, 1978, 1985, 1986; Vérité et al, 1984). It is probably due to lower microbial nitrogen production. In particular, the ammonia concentration was close to the minimal value required for maximal microbial synthesis (22 $\mathrm{mg} / \mathrm{l}$ according to Slyter et al, 1979). Due to the decrease of apparent digestibility of NAN, the small in- 
testinal content of apparently digested NAN sharply decreased when plant has matured (ie 292 and $212 \mathrm{~g} / \mathrm{kg}$ OM, for the young and the more mature fresh grass, respectively). Thus it appears that plant maturity affects more strikingly nitrogen than energy value.

\section{Rate of passage of grass diets}

The advanced maturity did not affect FOR, in agreement with the results of Funk et al (1987). Grass TMRT was increased to small extent and this agrees with data previously obtained either with hay (Robles et al, 1981; Hunt et al, 1988) or with fresh grass (Krysl et al, 1987; Pond et al, 1987). By contrast with the present study, advanced maturity in those studies always led to a marked reduction of intake and a sharp fall in digestibility. Aitchinson et al (1986) limited grass intake per sheep to $18 \mathrm{~g} \mathrm{DM} / \mathrm{kg}$ live weight and did not observe any influence of the stage of grass regrowth on the retention time. The retention time of the small particles in the rumen did not change with grass maturity probably because FOR was not affected, the small particles being supposed to flow out of the rumen with the liquid phase. Thus, the slight increase in TMRT is fully explained by a longer T2. As the level of intake remained unchanged, it should be assumed that particulate retention time in the abomasum and caecum-proximal colon is not modified (Coombe and Kay, 1965; Grovum and Hecker, 1973). Thus the factor which is most likely to induce the longer TMRT observed with more mature grass may be an increase in the time required for the comminution of the coarse particles. This hypothesis is consistent with the higher content of non-digestible cellwall material in more mature grass which would have required longer mastication than the young grass comminution being achieved primarily by mastication (Ulyatt et al, 1986). This longer mastication would have stimulated salivary flow and the increase of the net inflow of water into the rumen (rumen outflow minus intake) with advancing maturity $(230 \mathrm{I}$ vs $150 \mathrm{l} / \mathrm{d}$ ) might also support this.

Concentrate TMRT is $13 \mathrm{~h}$ shorter than forage TMRT. This faster passage has been previously observed in dairy cows eating diets based on conserved forages (Prange et al, 1979; Colucci et al, 1982; Snyder et al, 1984; Shaver et al, 1986; Peyraud et al, 1989) and also, in this experiment, when maize silage diet was given. This difference is largely accounted for by a lower $\mathrm{T} 2$ and so may be mainly due to differences in comminution time, since the passage in caecum-proximal colon is not different in forage and concentrate particles (Peyraud and Mambrini, 1992).

\section{Comparison of grass with maize silage diets}

Water dynamics in the rumen are greatly influenced by the nature of the forage. FOR was $43 \%$ higher and volume $35 \%$ lower with grass than with maize silage diet. The high FOR values observed with the grass diets are similar to the results obtained for ryegrass, cocksfoot and white clover diets by JL Peyraud (average of $15 \% / \mathrm{h}$, unpublished results) with dairy cows eating 9-11 kg DM/d. Carruthers et al (1988) measured liquid dynamics in grazing dairy cows in mid-lactation and also obtained high values for FOR in spite of a low feed intake $(6.3 \mathrm{~kg} / \mathrm{d})$. FOR with the maize silage diet was comparable with the values generally observed when cows were fed conserved forages at the same level of intake (Snyder et al, 1984; Peyraud et al, 1989). The lower rumen volume observed with the grass diets was partly 
explained by the lower OM intake, but may also be a particular feature of fresh forage diets. Actually, at similar levels of intake, the fibrous mass in the rumen, and therefore the water content, might be lower due to the higher digestibility of fresh grass. Rumen liquid outflow showed only small variations between the 3 diets. This could be related to the fact that the frequency of reticular contractions generally show only minor changes (Baumont and Deswysen, 1991). Therefore, the higher FOR observed with grass diets could be the consequence of the lower rumen volume. The increase of NAN flow relative to DOMI with the grass compared to the maize silage diet may indicate a higher efficiency of microbial synthesis in association with the more rapid FOR. Indeed, it is well known that the efficiency of microbial synthesis is related to FOR (Harrison et al, 1975).

TMRT of grass particles was shorter than for maize silage particles only in the case of the young highly digestible grass $(-6.7 \mathrm{~h})$. Obviously, this difference could have been influenced by the lower intake observed with the grass diets, since TMRT is known to increase when intake decreases (Hartnell and Satter, 1979; Snyder et al, 1984; Shaver et al, 1986). In our laboratory, we have previously observed that reducing the level of intake (17-15 kg OM/ d) of cows fed the same diet as in experiment 2, increased forage TMRT (47-53 h) whilst TMRT was longer during the dry period $(64 \mathrm{~h} ; 12 \mathrm{~kg} \mathrm{OM} / \mathrm{d})$ than in midlactation (53 h; $17.2 \mathrm{~kg} \mathrm{OM} / \mathrm{d}$; Mambrini, 1990). Indeed, the passage of grass and maize silage particles was quite different. The retention time of small particles in the rumen was lower for the 2 grass diets probably as a consequence of the higher FOR. This is consistent with the suggestions of Faichney (1986) assuming that water is the major vehicle for the removal of small particles. By contrast, T2 was not shorter for the particles of the young grass but was even higher for the more mature grass. This difference may originate in a longer comminution time for the coarse particles of more mature grass distributed without being chopped. However, it may also be partly ascribed to a longer transit in the caecum-proximal colon with the grass diets due to the lower level of intake, as previously observed in sheep (Coombe and Kay, 1965; Grovum and Hecker, 1973).

Concentrate TMRT was always lower than, but highly correlated with, forage TMRT ( $r=0.84 ; n=9$ ). Thus when the same concentrate was used with the 2 grasses and the maize silage, shorter transit times were associated with the fresh forage. This effect is explained by the lowest retention of the small particles in the rumen with the grass diet as a consequence of the water dynamics already mentioned for forage particles. Widyobroto and Peyraud (1993) showed that concentrate TMRT was not affected by the level of concentrate (20-35\%, DM basis). Thus the transit of the concentrate, and consequently its nutritive value, seems to be dependent on the nature of diet.

\section{CONCLUSION}

Increasing the maturity of fresh grass influenced liquid and particle dynamics. The index of comminution time of coarse particles was increased with more mature grass compared to the highly digestible grass, yet the retention time of small particles in the rumen remained unaffected. Compared to conserved forages, fresh grass showed a rapid FOR which was probably responsible for the lower rumen retention time of small particles. The retention time of concentrate particles seemed to depend on the nature of the associated forage, more so than content of concentrate in the whole diet. 


\section{ACKNOWLEDGMENTS}

The authors are grateful to $R$ Vérité for making helpful criticisms and $C$ Chabanet for her advice in statistics and her availability.

\section{REFERENCES}

Aitchison EM, Gill M, Osbourn DF (1986) Effect of supplementation with maize starch and level of intake of perennial ryegrass hay on the removal of digesta from the rumen of sheep. Br J Nutr 56, 477-486

Baumont R, Deswysen AG (1991) Mélange et propulsion du contenu du réticulo-rumen. Reprod Nutr Dev 31, 335-359

Beever DE, Terry RA, Cammell SB, Wallace AS (1978) The digestion of spring and autumn harvested perennial ryegrass by sheep. $J$ Agric Sci Camb 90, 463-470

Beever DE, Thomson DJ, Ulyatt MJ, Cammel SB, Spooner MC (1985) The digestion of perennial ryegrass (Lolium perenne $L$ cv Melle) and white clover (Trifolium repens $L \mathrm{cv}$ Blanca) by growing cattle fed indoors. Br J Nutr 54, 763-775

Beever DE, Dhanoa MS, Losada HR, Evans RT, Cammell SB, France J (1986) The effect of forage species and stage of harvest on the processes of digestion occurring in the rumen of cattle. Br J Nutr 56, 439-454

Bull LS, Rumpler WV, Sweeney TF, Zinn RA (1979) Influence of ruminal turnover on site and extent of digestion. Fed Proc 38, 27132719

Carruthers VR, Bryant T, Cochrem AS, Leay M (1988) Quantity of digesta in the reticulorumen of cows differing in susceptibility to bloat. NZJ Agric Res 31, 111-119

Colucci PE, Chase LE, Van Soest PJ (1982) Feed intake, apparent diet digestibility and rate of particulate passage in dairy cattle. J Dairy Sci 65, 1445-1456

Coombe JB, Kay RNB (1965) Passage of digesta through the intestines of the sheep. Retention times in the small and large intestines. $\mathrm{Br}$ J Nutr 19, 325-338

Dhanoa MC, Siddons RC, France J, Gale DL (1985) A multicompartmental model to de- scribe marker excretion patterns in ruminant faeces. Br J Nutr 53, 663-671

Doreau M, Rémond B (1982) Comportement alimentaire et utilisation digestive d'une ration de composition constante chez la vache laitière en fin de gestation et début de lactation. Reprod Nutr Dev 22, 307-324

Doreau M, Delacroix A, Jouany JP, Durier C, Rémond $B(1990)$ The influence of physiological state and dietary nitrogen supply on digestion in the dairy cow. J Anim Sci 68, 1-8

Ellis WC, Beever DE (1984) Methods for binding rare earths to specific feed particles. In: Techniques in Particle Size Analysis of Feed and Digesta in Ruminants (PM Kennedy, ed) Canadian Society of Animal Science, 154165

Ellis WC, Matis JH, Lascano C (1979) Quantitating ruminal turnover. Fed Proc 48, 27022706

Faicheny GJ (1975) The use of markers to partition digestion within the gastrointestinal tract of ruminant. In: Digestion and Metabolism in the Ruminant (IW McDonald, $\mathrm{ACl}$ Warner, eds) $277-291$

Faichney GJ (1986) The kinetics of particulate matter in the rumen. In: Control of Digestion and Metabolism in Ruminants (LP Milligan, WL Grovum, A Dobson, eds) 173-195

Funk MA, Galyean ML, Branine ME, Krysl LJ (1987) Steers grazing blue grama rangeland throughout the growing season. 1. Dietary composition, digesta kinetics and ruminal fermentation. J Anim Sci 65, 1342-1353

Giger S, Pochet S (1987) Méthodes d'estimation des constituants pariétaux dans les aliments destinés aux ruminants. Bull Tech CRVZ Theix, INRA 70, 49-60

Grovum WL, Hecker JF (1973) Rate of passage of digesta in sheep: 2. The level of food intake on digesta retention times and on water electrolyte absorption in the large intestine. Br J Nutr 30, 221-230

Grovum WL, Williams VJ (1973) Rate of passage of digesta in sheep. 4. Passage of marker through the alimentary tract and the biological relevance of rate constants derived from changes in concentration of marker in the faeces. Br J Nutr 30, 313-328

Harrison DG, Beever DE, Thomson DJ, Osbourn DF (1975) Manipulation of rumen fer- 
mentation in sheep by increasing the rate of outflow of water from the rumen. $J$ Agric Sci Camb 85, 93-71

Hartnell GF, Satter LD (1979) Determination of rumen fill retention time and ruminal turnover rates at different stages of lactation in dairy cows. J Anim Sci 48, 381-392

Hoover WH (1986) Chemical factors involved in ruminal fiber digestion. J Dairy Sci 69, 27552766

Hunt CW, Lancaster LL, Parkinson JF (1988) Effect of grass hay maturity and supplementation on digestive kinetics and growth performance in beef steers. J Anim Sci 66 (Suppl 1), 341-342

Hyden S (1955) A turbidimetric method for determination of higher polyethylene glycols in biological materials. Ann R Agric Col Sweden 21, 139-145

INRA (1989) Ruminant Nutrition: Recommended Allowances and Feed Tables ( $R$ Jarrige, ed). Paris and London, INRA and John Libbey

Jouany JP (1982) Volatile fatty acid and alcohol determination in digestive contents. Sci Aliments 2, 131-144

Kennedy PM, Boniface AN, Liang ZJ, Muller D, Murray RM (1992) Intake and digestion in swamp buffaloes and cattle. 2. The comparative response to urea supplements in animal fed tropical grasses. J Agric Sci Camb 199, 243-254

KrysI LJ, Galyean ML, Judkins MB, Branine ME, Estell RE (1987) Digestive physiology of steers grazing fertilized and non-fertilized blue grama rangeland. $J$ Range Manage 40 , 493-501

Legoffe $P$ (1991) Méthodes d'étude et facteurs de variation de la dégradabilité de l'azote des fourrages verts dans le rumen. Thèse de l'École Nationale Supérieure Agronomique de Rennes, $88 p$

Malawer SJ, Powell DW (1967) An improved turbidimetric analysis of polyethylene glycol utilizing an emulsifier. Gastroenterology 53, 250-256

Mambrini M (1990) Étude du transit des aliments dans le tube digestif des vaches laitières : aspects méthodologiques et facteurs de variation. Thèse de Doctorat, Université de Rennes, France, $171 \mathrm{p}$
Mambrini M, Peyraud JL (1990) Dynamique de l'eau dans le rumen des vaches laitières: facteurs de variation et relation avec le transit des particules. Reprod Nutr Dev 30 (suppl 2), 183s-184s

Mambrini M, Peyraud JL (1992) Passage rate of liquid and particles in the digestive tract of dairy cows fed fresh forage. Ann Zoot 41,6768

Mambrini M, Peyraud JL, Rulquin H (1988) Comparaison de différentes méthodes de calcul du temps de séjour des résidus alimentaires dans l'ensemble du tube digestif chez la vache laitière. Reprod Nutr Dev 28 (suppl 1), 149-150

Mertens DR, Ely LO (1982) Relationship of rate and extent of digestion to forage utilization. A dynamic model evaluation. J Anim Sci54 (4), 895-905

Ørskov ER, Ojwang I, Reid GW (1988) A study on consistency of differences between cows in rumen outflow rate of fibrous particles and other substrates and consequences for digestibility and intake of roughages. Anim Prod 47, 45-51

Peyraud JL (1994) Comparaison de la digestion du trèfle blanc et des graminées prairiales chez la vache laitière. Fourrages (in press)

Peyraud JL, Mambrini M (1992) Direct measurements of transit times in the stomachs and intestines of the dairy cow. Ann Zoot 41, 55

Peyraud JL, Mambrini M, Rulquin H (1989) Transit time measured by rare earth elements in dairy cows fed three diets offered at two levels of feed intake. Asian Austr J Anim Sci 2, 366-367

Pond KR, Ellis WC, Lascno CE, Akin DE (1987) Fragmentation and flow of grazed coastal bermudagrass through the digestive tract of cattle. J Anim Sci 65, 609-618

Prange RW, Jorgensen NA, Satter LD (1982) Rate of passage calculation based on duodenal or faecal collection sites. J Dairy Sci 65 (suppl 1), 145

Robles AY, Beleya RL, Martz FA (1981) Intake, digestibility, ruminal characteristics and rate of passage of alfalfa diets fed to sheep. J Anim Sci 53, 774-779

SAS (1987) SAS User's Guide, statistics SAS Institute, Cary, NC

Shaver RD, Nytes AJ, Satter LD, Jorgensen NA (1986) Influence of amount of feed intake 
and forage physical form on digestion and passage of prebloom alfalfa hay in dairy cows. J Dairy Sci 69, 1545-1559

Shaver RD, Satter LD, Jorgensen NA (1988) Impact of forage fiber content on digestion and digesta passage in lactating dairy cows. J Dairy Sci 71, 1556-1565

Slyter LL, Satter LD, Dinius DA (1979) Effect of ruminal ammonia concentration on nitrogen utilization by steers. J Anim Sci 48, 906-917

Snyder TJ, Muller LD, Rogers JA, Abrams SM (1984) Digesta passage measured by markers in dairy cows fed two ratios of corn silage: grain with 0 or $1.2 \%$ sodium bicarbonate. J Dairy Sci 67, 1953-1964

Uden $P$ (1984) Digestibility and digesta retention in dairy cows receiving hay or silage at varying concentrate levels. Anim Feed Sci Technol $11,279-291$
Ulyatt MJ, Dellow DW, John A, Reid CSW, Waghorn GC (1986) Contribution of chewing during eating and rumination to the clearance of digesta from the ruminoreticulum. In: Control of Digestion and Metabolism in Ruminants (LP Milligan, WL Grovum, A Dobson, eds), 498-515

Van Soest PJ (1963) Use of detergent analysis of fibrous feed. II. A rapid method for the determination of fiber and lignin. $J$ Off Agric Chem 46, 829-835

Vérité $R$, Rémond $B$, Journet $M$ (1984) Sites of organic matter and protein digestion in lactating cows fed fresh grass from spring to autumn. Can J Anim Sci 64, 328-329

Widyobroto BP, Peyraud JL (1993) Effect of varying the proportion of concentrate with the same starch content in the diet on passage rate and on ruminal digestion in cows. Ann Zootech 42, 154 